\title{
Influences of gender on academic achievement of Fiber Optic Communication System: An experience of Politeknik Merlimau Melaka
}

\author{
Rosita Zainal ${ }^{1}$, Rodzah Yahya ${ }^{1}$, Khadijah Abdul Rahman ${ }^{1}$ \\ I'Department of Electrical Engineering, Politeknik Merlimau, Malacca, Malaysia)
}

\begin{abstract}
This article discusses the differences in academic performance among male and female students in the education system at the Politeknik Merlimau Melaka. This study is an exploratory study using secondary data based on the assessment of coursework and final examination of Fiber Optics Communication System subject for a period of three semesters. Data were analyzed using descriptive and inferential using Statistical Package for Social Science (SPSS) package. There was a significant relationship between gender and academic achievement. $t$-test showed that the mean performance of male and female differ significantly $(t=3.33, p$ $<0.05)$. This means that female students have a mean significantly higher than male students in the achievement of a fiber optics communication system. However, this difference is very small. Apart from gender differences it also also found that other factors such as learning styles also contribute to students' academic performance.
\end{abstract}

Keywords - Gender, Academic achievement, fiber optics communication system, Politeknik Merlimau

\section{Introduction}

In the era of globalization and technological revolution, education plays an important role in the development of human capital and are associated with individual well-being and opportunities for a better life [1]. Known that the sixth challenge of Vision 2020 is to invite the community in Malaysia to evolve from simply being consumers of technology to contribute scientific and technological civilization of the future. Therefore, establishment of polytechnics in the country is to provide opportunities for high school graduates to continue their studies in the field of technology and engineering that indirectly contribute to the development of human capital in science and technology for national needs. According to statistics released by the Ministry of Higher Education Malaysia, number of female students pursuing studies in engineering, manufacturing and construction are smaller than male where only $31.7 \%$ in 2011 and $30.2 \%$ in 2012 (Table 1). Optical fiber communication system is one of the subjects in the sciences and engineering group is seen as for preparation to lead students into the field of science and technology. Optical fiber communication system is a subject that should be taken by students who are pursuing a Diploma in Electrical Engineering. This course is offered in semester two for second year students. This course provides students the opportunity to explore the field of communication systems in electrical engineering. This study aims to analyze the performance of male and female students in Fiber Optics Communications System for Diploma in Electrical Engineering for three academic sessions. This study also analyze other factors that contribute to the differences in academic performance among male and female students through survey method. Research questions are: -

1. What are the patterns and trends of performance differences among male and female students in Fiber Optics Communications System?

2. To what extent differences in the factors that are assumed to be influence performance among male and female students?

Table 1: Number of graduates by gender on the field at polytechnics 2011-2012 (Ministry of Higher Education Statistical Report)

\begin{tabular}{|c|c|c|c|c|c|c|}
\hline \multirow{2}{*}{ Field } & Year & $\begin{array}{c}\text { Male } \\
\text { students }\end{array}$ & $\begin{array}{c}\text { Female } \\
\text { students }\end{array}$ & Total & $\begin{array}{c}\text { Male percentage } \\
(\%)\end{array}$ & $\begin{array}{c}\text { Female } \\
\text { percentage (\%) }\end{array}$ \\
\hline $\begin{array}{c}\text { Arts \& } \\
\text { Humanities }\end{array}$ & 2012 & 151 & 186 & 337 & 44.8 & 55.2 \\
\cline { 2 - 7 } & 2011 & 128 & 208 & 336 & 38.1 & 81.9 \\
\hline $\begin{array}{c}\text { Social Sciences, } \\
\text { Business \& } \\
\text { Consulting }\end{array}$ & 2012 & 1,079 & 4,418 & 5,497 & 6.4 & 17.7 \\
\hline $\begin{array}{c}\text { Science, } \\
\text { Mathematics and } \\
\text { Computer }\end{array}$ & 2011 & 1,110 & 5,153 & 6,263 & 35.4 & 64.6 \\
\hline Engineering, & 2012 & 662 & 1,207 & 1,869 & 36.7 & 63.3 \\
\hline
\end{tabular}


Influences of gender on academic achievement of Fiber Optic Communication System: An experience of

\begin{tabular}{|c|c|c|c|c|c|c|}
\hline $\begin{array}{c}\text { Manufacturing \& } \\
\text { Construction }\end{array}$ & 2011 & 15,844 & 7,359 & 23,203 & 68.3 & 31.7 \\
\hline \multirow{2}{*}{ services } & 2012 & 308 & 883 & 1,191 & 25.9 & 74.1 \\
\cline { 2 - 7 } & 2011 & 380 & 1,212 & 1,592 & 23.9 & 76.1 \\
\hline
\end{tabular}

\section{Literature Review}

In the context of education, gender differences related to academic performance has been one of the interesting issues to be studied. There is an ongoing debate on the controversial issue of gender differences on academic achievement. The relationship between gender differences in academic achievement has been the focus of researchers in the past. Oxford and Crookall [2] argues that one of the areas that should be focused on the study of language learning strategies (LLS) is gender. According to theories of gender, men and women entering the education system with a set of behaviors, attitudes and values that are different [3]. Studies on the influence of gender and academic performance of students is increasing in diverse disciplines. One is the result of research by Deepak et al. [4] showed that female medical students over male students in the evaluation of the overall test. Similarly, according to a study by [5-7] female medical students performed better than male medical students in clinical examination based on performance. Similarly, a survey by Sutherland [8] states that it is a comprehensive phenomenon where the performance of female students better than male students and occurs in many countries in the world such as in Scotland, England, France, Germany, Japan, Australia, and New Zealand. Contrary to [9] who found a significant gender effect in favor of the male in the field of science in the overall performance.

Results from the study by [10] shows that there is no difference in academic performance between male and female. In addition the studies by [11] also found that there are no differences in gender performance. RecentlyThe most comprehensive review of research in the field of gender differences have shown very little real difference between the mathematical and verbal abilities between men and women [12]. According to [13], there is evidence of a growing gap in educational attainment between genders in several developing countries over the last decade. The level of students achievement in the learning process depends more on attitude, interest and motivation continued, including the concept of self-directed learning [14]. The research related to gender differences in educational attainment is very broad and complex. Many explanations have been given and the explanation also includes a variety of factors such as biology, theories of gender and school factors [15].

In Malaysia, the excellent performance of female students is associated with a total enrollment of female students in public higher education institutions (IPTA) in excess of the male students. Imbalance of male and female students at the university will be the socio-political implications and serious injury to the national economy. Therefore, this study was undertaken to examine gender differences in academic performance among students in the course of Optical Fiber Communication Systems at Polytechnic Merlimau Melaka hoping to get input that will make recommendations on measures to improve the performance of both sexes.

\section{Research Methodology}

This study involved 73 students from different academic session in the Department of Electrical Engineering, Polytechnic Merlimau, Melaka. The information obtained in this study are based on the results of assessment of course work, final examination and overall assessment. Four factors were selected as variables for this study, namely gender, performance of course work assessment, final examination and overall academic achievement. Academic performance as measured by their scores in exams. The samples composed of students from three different cohort (Table 1).

Table 1: Profile of sample

\begin{tabular}{|c|c|c|c|}
\hline Cohort & Gender & Frequency & Percentage \\
\hline \multirow{2}{*}{1} & Male & 13 & $44.8 \%$ \\
\cline { 2 - 4 } & Female & 16 & $55.2 \%$ \\
\hline \multirow{2}{*}{2} & Male & 13 & $61.9 \%$ \\
\cline { 2 - 4 } & Female & 8 & $38.1 \%$ \\
\hline \multirow{2}{*}{3} & Male & 9 & $39.1 \%$ \\
\cline { 2 - 4 } & Female & 14 & $60.9 \%$ \\
\hline
\end{tabular}

Data was analyzed by using the program Statistical Package for Social Science (SPSS). Data were presented as descriptive and inferential. For descriptive data analysis used was the mean score and standard deviation. For inferential data, the analysis used, the t-test correlation. A structured questionnaire was also used to obtain information related to this study, we only focus on the achievement of these courses. 


\section{Results And Discussion}

In this study, there were 37 persons (50.68\%) females and 36 (49.32\%) male students. Mean achievement in course work is 70 for female and male only 66 . Standard deviation for female students is only 6 compared to male students 6.2832 . Mean score for the final exam is 44 female students than male students only 41. Standard deviation is 10 female students than male students 11 .

Table 2 Distribution of fiber optics communications system performance by cohort, gender, course work, final examination and overall performance.

\begin{tabular}{|c|c|c|c|c|}
\hline \multicolumn{2}{|c|}{$\begin{array}{l}\text { Variables } \\
\text { Gender }\end{array}$} & Mean & Standard Deviation & $\mathbf{N}$ \\
\hline \multirow{2}{*}{$\begin{array}{l}\text { Assessment of } \\
\text { Coursework }\end{array}$} & Male & $\begin{array}{l}66 \\
16 \\
\end{array}$ & 6.2832 & \multirow{2}{*}{73} \\
\hline & Female & 70 & 6 & \\
\hline \multirow{2}{*}{ Final Exam } & Male & 41 & 11 & \multirow[b]{2}{*}{73} \\
\hline & Female & 44 & 10 & \\
\hline \multirow{2}{*}{ Overall performance } & Male & 54 & 8 & \multirow{2}{*}{73} \\
\hline & Female & 57 & 6 & \\
\hline
\end{tabular}

The overall mean score of female students is 57 compared to male only 54 . Whereby standard deviation female is 6 compared to male which is 8 . The analysis shows that there is a significant relationship between student achievement and gender at $p<0.05$. Female students have a higher mean than male students for course work, final examination and overall assessment. Overall, female students obtain better results than male in almost all types of assessments. The results showed that female students have a higher mean score than male students. From the questionnaire it was found that this performance difference may be due to other factors such as background and different learning styles. Among the factors that may be associated with the academic performance of female students better than male students are their learning styles.

\section{Conclusion}

This study found that there was statistically significant differences between female and male students in academic performance. Variances by gender was analyzed using t-test showed that the mean performance of male and female differ significantly $(\mathrm{t}=3.33, \mathrm{p}<0.05)$. This means that female students have a mean significantly higher than male students in the achievement of a Fiber Optics communication system. However, this difference is very small. Apart from gender differences it is also found that factor such as learning style also contribute to a student's academic performance.

\section{Acknowledgements}

The authors would like to thank Department of Electrical Engineering for their help and support in collecting students' grades. Thanks are also extended to the students who are involved in the survey questions.

\section{References}

[1] J. Battle, and M. Lewis, The increasing significance of class: The relative effects of race and socioeconomic status on academic achievement, Journal of Poverty, 6(2), 2002, 21-35.

[2] R. Oxford, and D. Crookall, Research on six situational language learning strategis: Methods, findings and instructional issues. Modern Language Journal, 73 (4), 1989.

[3] M. Weaver-Hightower, The 'boy turn' in research on gender and education, Review of Educational Research, 73(4), 2003, 471-498.

[4] K.K. Deepak, K.U. Al-Umran, M.H. Al-Sheikh, and A. Al-Rubaish, The influence of gender on undergraduate performance in multiple choice testing in clinical disciplines at University of Dammam, Saudi Arabia, Al Ameen Journal of Medical Science, 4(2), 2011, 123-130.

[5] OO. Omigbodun and AO. Omigbodun, Influence of gender on undergraduate performance in psychiatry at Ibadan, Nigeria. Med Educ, 37(12), 2003, 1091-93.

[6] F.A. Sawair, Z.H. Baqain, Al-Omari ikh, FK. Wahab and L.D. Rajab, Effect of gender on performance of undergraduate dental students at the University of Jordan, Amman, Journal Dent Educ., 73(11), 2009, 13 -19.

[7] S.A. Haist, J.F. Wilson, C.L. Elam, A.V. Blue, and S.E. Fosson. The Effect of Gender and Age on Medical School Performance: An Important Interaction, Adv Health Sci. Educ. Theory Pract., 5(3), 2000, 197-205.

[8] T.Tinklin, L. Croxford, B. Frame, A. Ducklin, Gender and pupil performance in Scotland, Paper work, The european conference on educational research, Edinburgh. Available online: http:www///leeds.ac.uk/educol/documents/00001663.htm.

[9] T. DeBaz, Meta-analysis of the relationship between students' characteristics and achievement and attitudes toward science. Columbus, OH: ERIC Clearinghouse for Science, Mathematics, and Environmental Education. (ERIC Document ED377079). Columbus, OH: ERIC Clearinghouse for Science, Mathematics, and Environmental Education. (ERIC Document ED377079), 1994.

[10] Chinwuba Ambrose Okafor and Osamuyimen Egbon, Academic Performance of Male versus Female Accounting Undergraduate Students: Evidence from Nigeria undergraduate students, Higher Education Studies, 1(1), 2011 
[11] M.G. Lipe, Further Evidence on the Performance of Female Versus Male Accounting Students. Issues in Accounting Education, Spring, 144-152, 1989.

[12] D.F. Halpern, Sex differences and cognitive abilities (Mahwah, NJ: Erlbaum. 2000)

[13] M. Weaver-Hightower, The 'boy turn' in research on gender and education. Review of Educational Research, 73(4), 2003, 471-498.

[14] Crow \& Crow, Psikologi Pendidikan (Kuala Lumpur: Dewan Bahasa dan Pustaka, 1983).

[15] Sheree J. Gibb, David M. Fergusson and L. John Horwood, Gender differences in educational achievement to age 25, Australian Journal of Education, 52(1), 2008, 63-80. 